\title{
Travelling more over time: making an in-situ exhibit at the Montréal-du-Gers palaeontological site (France)
}

\author{
Itahisa Déniz-González ${ }^{1}$, Francis Duranthon²
}

Received: 13-07-2012

Accepted: 15-12-2012

\begin{abstract}
There are more ancient remains in palaeontological sites than in archaeological ones, and the structures of habitat or the traces of human activity are absent. In the Miocene dig of Montréaldu-Gers, remains of mammals, gastropods and pollen have been found, and they have make it possible for scientists to decode the past of the region. Among the fossils extracted, in a good state of conservation, there are four new species. For all these reasons, this site has a high heritage value.

Now, it is time to bring this knowledge closer to the public, as well as its process of creation. Therefore, two plannings have been articulated; one for the conditioning and one for interpretive work that will guide the action of the Natural History Museum of Toulouse (Toulouse City Council) about heritage interpretation. The objective of the plan is to develop a geoturism experience, using thematic interpretation and defining the interpretive resources and services to implement in the site. This plan includes a prevision of infrastructures, equipments and media to transmit the message to the visitor in an organized and coherent way.
\end{abstract}

Keywords: valorisation; palaeontological site; France; interpretive plan; geoturism.

Resumen. Viajando más allá del tiempo: el proyecto de musealización in situ del yacimiento paleontológico de Montréal-du-Gers (Francia)

Los yacimientos paleontológicos presentan restos más antiguos que los documentados en yacimientos arqueológicos, y las estructuras de hábitat o las trazas de actividad humana están ausentes. En la excavación miocena de Montréal-du-Gers, han sido recuperados restos de mamíferos, gasterópodos y polen. Estos restos han permitido a los científicos interpretar el pasado de la región. Entre los fósiles recuperados, que están en buen estado de conservación, se encuentran cuatro especies nuevas. Por estas razones, el yacimiento presenta un alto valor patrimonial.

Ahora es el momento de transmitir este conocimiento al público, así como su proceso de creación. Para ello, se han puesto en marcha dos planes, uno para el acondicionamiento del yacimiento y el otro

1. Muséum d'Histoire Naturelle de Toulouse. 35 Allées Jules Guesde 31000 Toulouse, France. itahisadg@gmail.com

2. Muséum d'Histoire Naturelle de Toulouse. 35 Allées Jules Guesde, 31000 Toulouse, France. AMIS UMR 5288. francis.duranthon@mairie-toulouse.fr 
para el trabajo interpretativo que guiará las acciones del Museo de Historia Natural de Toulouse (Ayuntamiento de Toulouse) acerca de la interpretación patrimonial. El objetivo del proyecto es desarrollar una experiencia de geoturismo empleando la interpretación temática y definiendo los recursos interpretativos que se deben implementar en el yacimiento. El plan incluye la previsión de infraestructuras, equipamientos y medios para transmitir los contenidos a los visitantes de forma organizada y coherente.

Palabras clave: valorización; yacimiento paleontológico; Francia; plan interpretativo; geoturismo.

Resum. Viatjant més enllà del temps: el projecte de museïtzació in situ del jaciment de Montréal-du-Gers (França)

Els jaciments paleontològics presenten restes més antigues que les documentades als jaciments arqueològics, i les estructures d'hàbitat o les traces d'activitat humana hi són absents. En l'excavació miocena de Montréal-du-Gers, hi han estat descobertes restes de mamífers, gasteròpodes i pol.len. Aquestes restes han fet possible que els científics poguessin interpretar el passat de la regió. Entre els fossils recuperats, que es troben en bon estat de conservació, hi ha quatre espècies noves. Per aquestes raons, el jaciment presenta un alt valor patrimonial.

Ara és el moment de transmetre aquests coneixements al públic, així com el procés de creació. Per aquesta raó, s'han posat en marxa dos plans, un per condicionar el jaciment i l'altre per fer el treball interpretatiu que guiarà les accions del Museu d'Història Natural de Tolosa (Ajuntament de Tolosa) al voltant de la interpretació patrimonial. L'objectiu del projecte és desenvolupar una experiència de geoturisme emprant la interpretació temàtica i definint els recursos interpretatius que caldrà implementar al jaciment. El pla inclou la previsió d'infraestructures, equipament i mitjans per transmetre els continguts als visitants de forma organitzada i coherent.

Paraules clau: valorització; jaciment paleontològic; França; pla interpretatiu; geoturisme.

DÉNIZ-GONZÁLEZ, Itahisa; DURANTHON, Francis. «Travelling more over time: making an in-situ exhibit at the Montréal-du-Gers palaeontological site (France)». Treballs d'Arqueologia, 2013, núm. 19, p. 41-51.

\section{Introduction}

In the palaeontological digs, more ancient remains can be found than in archaeological sites. The habitat structures and the traces of human activity are absent. The palaeontological site of Montréal-du-Gers was formed in the Early Miocene and holds notable vertebrates fauna, which allows it being an international reference (De Brujin et al., 1992). The site is a sedimentary deposit formed during different geological processes, allowing us to reveal the region geological history.
The interest of the site as geological heritage is unquestionable, and it is included in different geological heritage inventories. The inventories are interested in collecting information about geosites, that is aimed to be used in their management and valorisation, but this site has already been a ground for students activities before been listed.

Until now, both didactic and scientific activities have been developed with a close collaboration. A real scientific activity has been the basis of learning, while the work that young people develop takes 
a part in the conservation of the fossils, used as well in scientific research.

Nowadays, we are working to give the site the necessary elements for its touristic valorisation, allowing people to enjoy and learn from it through the discovery of a real active excavation and real scientific methodology. Data obtained with these activities might allow the creation of new knowledge. This valorisation is developed under the frame of a transboundary cooperation project about sustainable tourism.

\section{Before the archaeological timescale}

In the palaeontological sites a variety of fossils and trace fossils can be found: internal and external molds, fossils created after de replacement of the organisms tis- sues by minerals, the recrystallization of the skeleton, etc. They can be microscopic or have a size of various meters.

Trace fossils include any kind of impression due to life. For instance, ichnites include footprints or feeding marks. Age of fossils can vary from billions of years to Holocene, so, in the palaeontological sites we can find more ancient remains than in archaeological sites.

This way, we are able to point out the different scales and different kinds of remains palaeontologist deal with. The structures of habitat and the traces of human activity are absent. However, timelines overlap some times, and it is then difficult to define the border line between the time of palaeontology and time of archaeology.

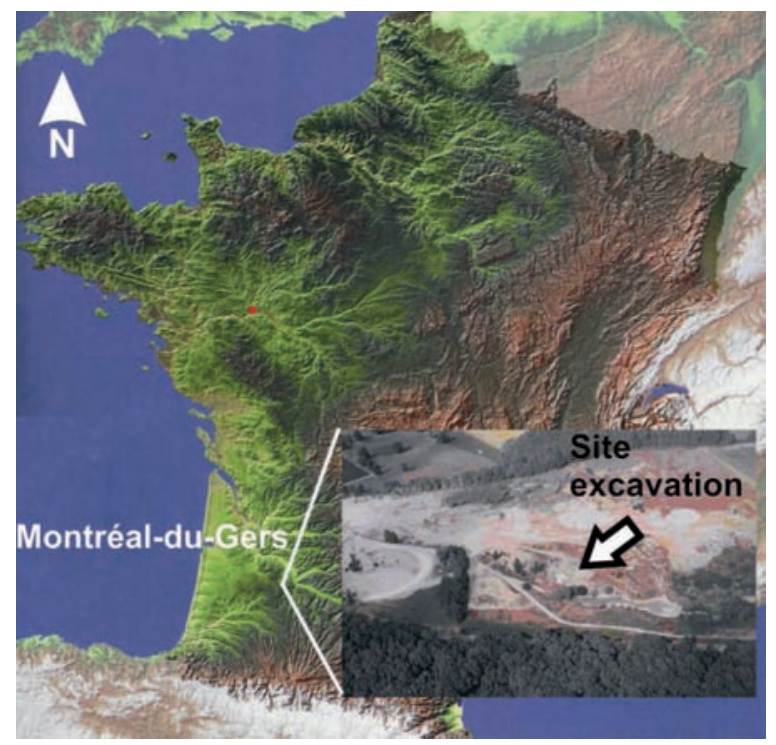

Figure 1. Emplacement and aerial view of the palaeontological site of Montréal-du-Gers (Gers department, Midi-Pyrénées region, France). The site was found by accident in 1987 during the mining of the limestone next to it (Duranthon, unpublished). 


\section{Localisation and geological context}

The site of Montréal-du-Gers, known as well as Béon 1, is located in the Gers department, Midi-Pyrénées region, in the south of France (figure 1).

The site was discovered by accident during the exploitation of a limestone quarry next to it (Crouzel et al., 1988). Dated in Lower Miocene (Tertiary, near $17 \mathrm{Ma}$ ), an important mammals fauna from the biozone MN4 (Burdigalian) has been found.

The geological cut at Montréal-duGers includes the trilogy of Agenais (figure 2):

- Agenais white continental limestone.

- Marine marls containing Ostrea Aginensis.

- Agenais grey continental limestone.

However, in the fossils site we find the following succession of strata:

- Continental limestone.

- Brown clay. At the bottom, fossils are generally broken, and long bones, with a preferential orientation, are packed in sediments with a relatively low sorting. In the rest of the strata, skeletons are connected. Locally, important concretions and orientation of bones in the palaeo-slope are observed.

- White clay. Higher quality skeleton in anatomic connection are found, but in a smaller quantity.

- Continental limestone.

Up to the moment, more than 90 species of vertebrates, including mammals, reptiles and birds have been cited, including four new species: Ampelomeryx

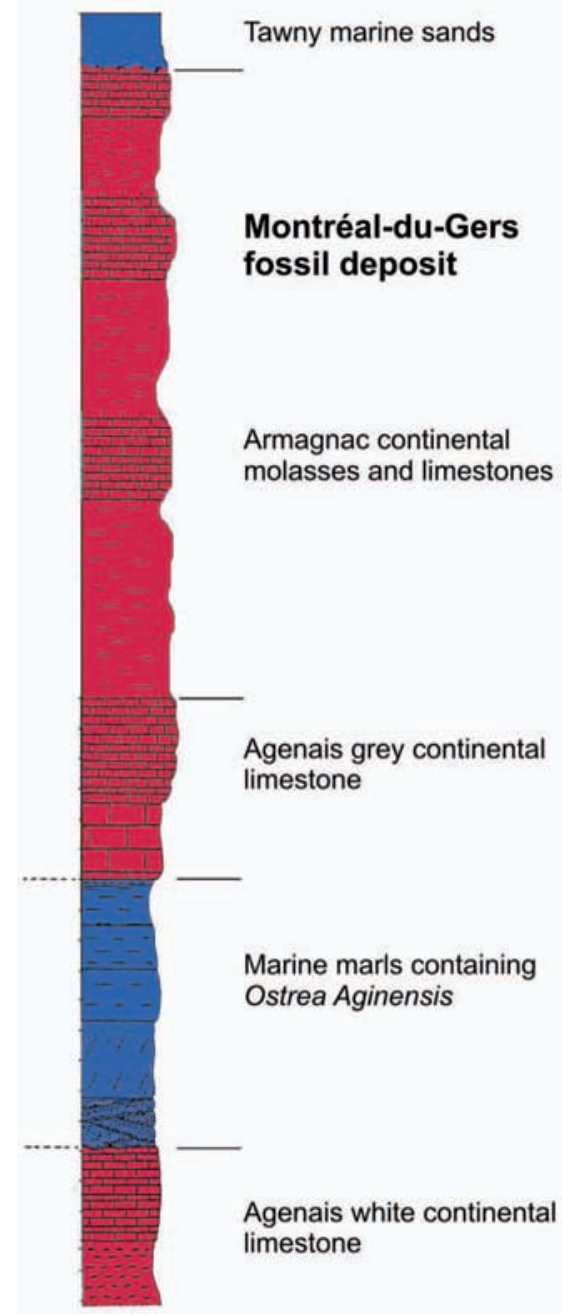

Figure 2. Synthetic geological cut of the Montréal-du-Gers region, which is a sedimentary sequence including materials with marine and continental origins. The Agenais white continental limestone is at the bottom, followed by a marine marl layer containing Ostrea aginensis, above it, the Agenais grey limestone, the Armagnac continental molasses and limestone those have the fossils associated, and a marine sands layer on top (Duranthon, unpublished). 
1

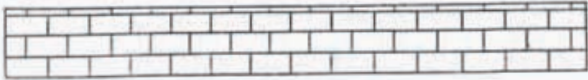

ALTERATION

2

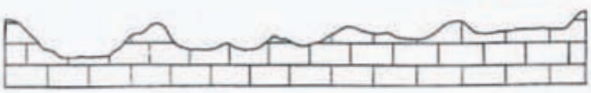

FLUVIO-LACUSTRINE DEPOSITS

3

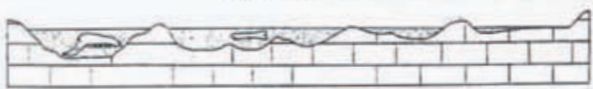

SEDIMENTARY CONTRIBUTIONS + TRAMPLING

4

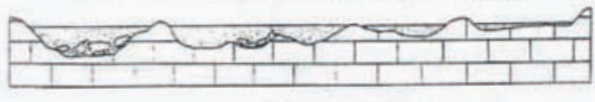

COARSE SEDIMENTS INPUTS

5

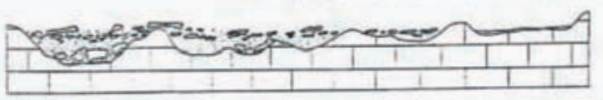

CONSOLIDATION, NODULES FORMATION

6

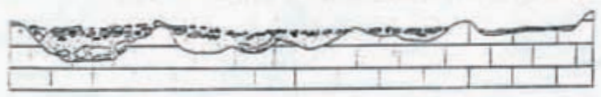

FINE-GRAINED SEDIMENTS INPUTS

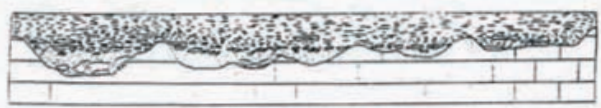

FINE-GRAINED SEDIMENTS INPUTS PEDOGENESIS

8

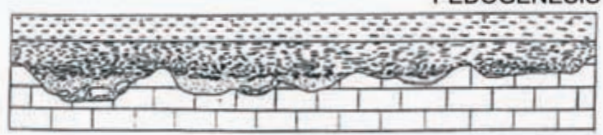

LAKE SEDIMENTS
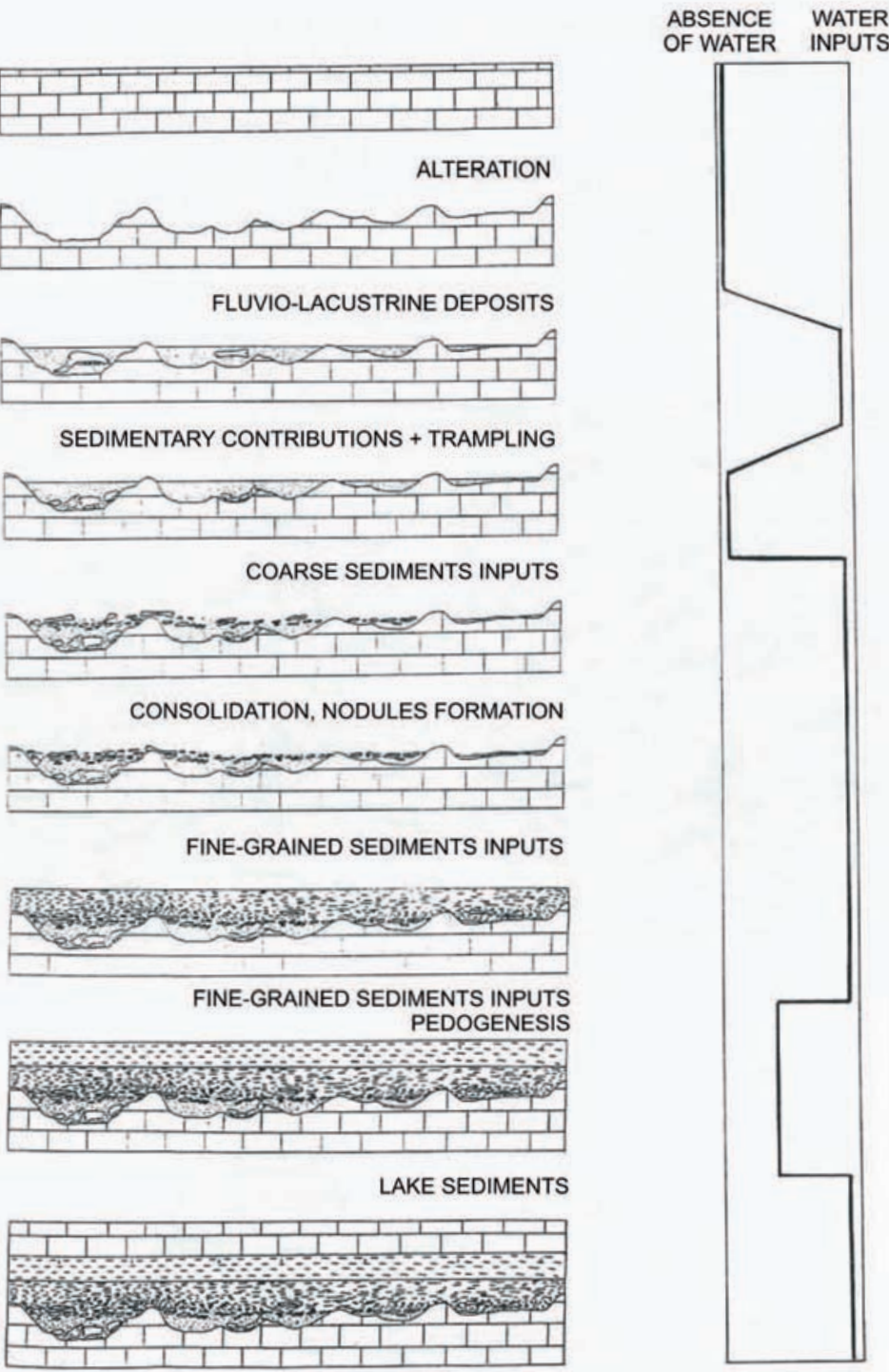

OF WATER INPUTS

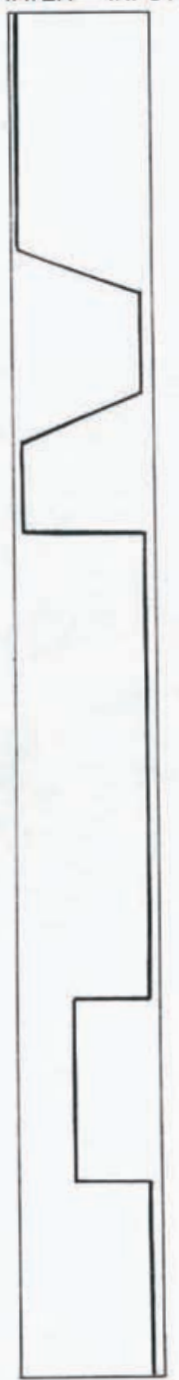

Figure 3. Geologic history of the deposit summarized in nine stages and their relationship with the presence of water. Stages: 1) limestone deposits; 2) limestone alteration; 3) fluvio-lacustrine contributions; 4) fluvio-lacustrine contributions and trampling; 5) coarse sediments inputs; 6) consolidation and nodules formation; 7) fine-grained sediments contribution; 8) fine-grained sediments inputs and pedogenesis, 9) limestone lake deposits (Duranthon et al., 1999). 
ginsburgi (Duranthon et al., 1995), of the Palaeomerycidae family; Hispanotherium (Aegyrcitherim) beonense (Antoine and Duranthon, 1997), of the Rhinocerotidae family; Eurolistriodon tenarezensis (Orliac, 2006) and Hyotherium lacaillei (Orliac et al., 2006), of the Suidae family. Gastropods and pollen have also been listed. Some of the species have been listed for first time in the region.

The analysis of the deposits has made possible the reconstruction of the geological history, corresponding to a switch back and forth from inundation to dry periods due to a swamp (figure 3).

The site is included in different inventories of geological heritage; the Gers Department Inventory of Palaeontological Heritage (Welcomme and Crochet, 1996) and in the Midi-Pyrénées Inventory of Geological Heritage (Commission Régionale du Patrimoine Géologique, unpublished). The MidiPyrénées Inventory of Geological Heritage is a part of the National Inventory of Geological Heritage. This inventory was conducted under a common method for the all French territory (De Wever et al., 2006). In this inventory, the site has been listed as geosite with international relevance.

\section{Valorisation of the site}

The excavation has been in activity since 1988 to 2006: one month and a half every summer. The activity in the excavation has been developed as an educational activity intended for teenagers and university students. They remained responsible for the findings no matter the importance of their value: the students were in charge of the excavation, reparation, catalogue and conditioning of any specimen until their transfer to the Muséum de Toulouse (Duranthon and Sarot, 2006) (figure 4).

The piece of land where the fossil site is included was acquired in 1997 by the Toulouse City Council (Mairie de Toulouse). It is managed by the Natural History Museum of Toulouse.

Collected specimens are currently displayed at the Museum de Toulouse. In the corridor Continuum et ruptures, where the evolution of life is shown, the period concerning Lower Miocene is represented with a stop in the timeline via the example of the palaeontological site of Montréal-du-Gers. One room is dedicated to this site, where molds of the dig are presented, under the context of the excavation activity. A video shows the activity and explains the formation process of the deposit. This is the scenario where some fossils (and molds) belonging to Montréal-du-Gers are presented.

Today, the Museum de Toulouse works on setting up the right conditions for excavations and visitors reception. The Origenes EFA 127/09 project frames this action. Its main objective is to «Promote during the following years, an innovative tourism model, respectful with the environment and valorising the natural and historic existent heritage, as well as the scientific knowledge that this heritage generates». To achieve this objective a sustainable touristic route around the Pyrenees is in development: «The Origins Road». "The Origins Road» includes activities related to Astronomy, Palaeontology and Archaeology.

All the right conditions will make this site open and safe to all, including the visitors with physical disabilities. The excavation campaign conditions will be improved at the same time. 

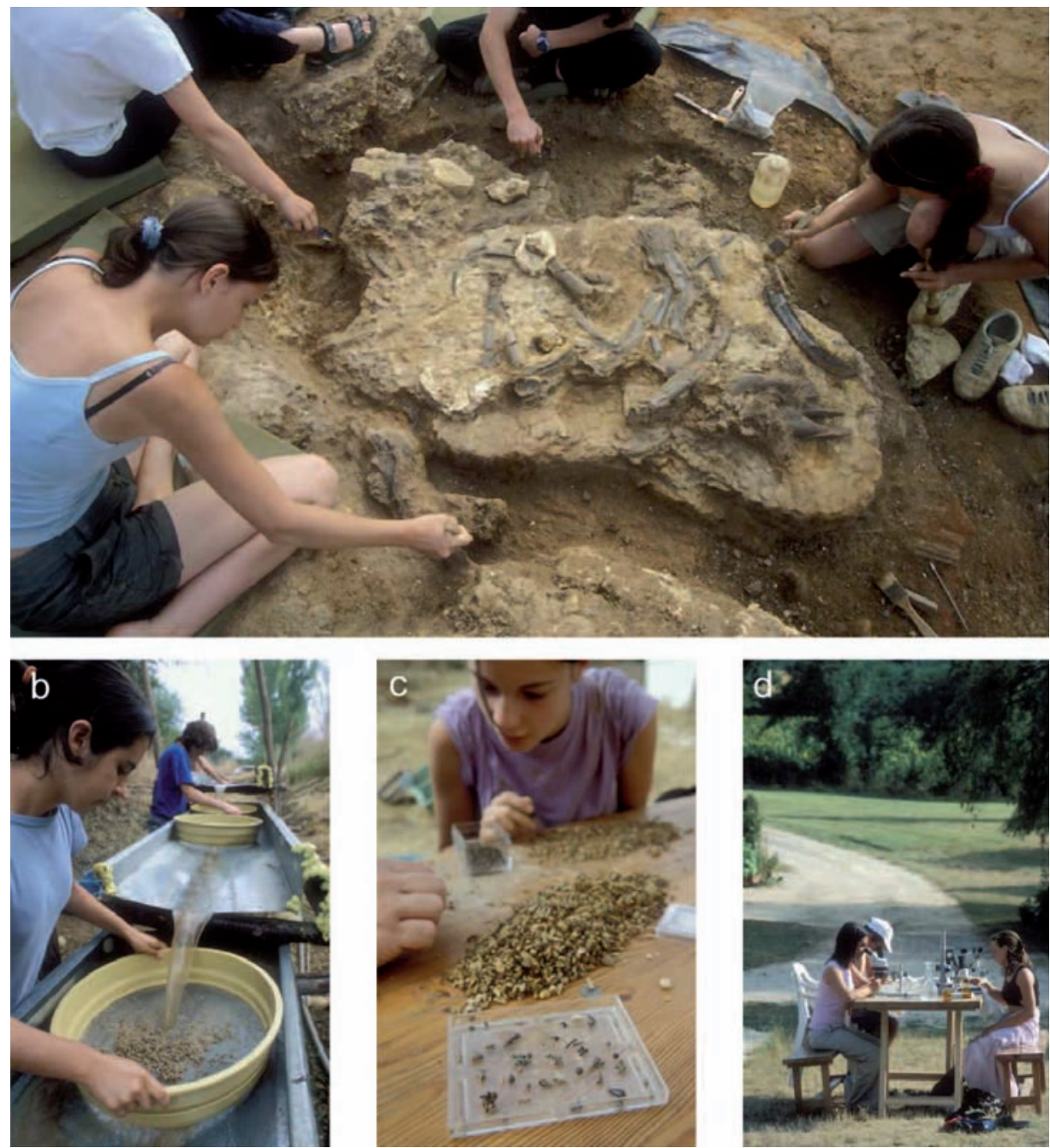

Figure 4. Teenagers and university students in a real paleontological excavation during a work camp. Work camps promote learning the scientific methodology by discovering it. The teenager or university student is the only responsible; he/she follows all the stages until the transference of the fossil to the Natural History Museum of Toulouse: a) bones accumulation dug out by teenagers and university students; b) screening tasks; c) identifications tasks made by naked eye, and d) examination with magnifying glasses. () Muséum de Toulouse/L.Bessol/cNature) 
Travelling more over time: making an in-situ exhibit at the Montréal-du-Gers palaeontological site (France)

The site will be covered with a fabric building of approximately $450 \mathrm{~m}^{2}$, surrounded with walkways or footbridges permitting disabled people accessing to observe de dig. Next to it, the facilities (a meeting room, a stock room, adapted water closets, security shower, etc.) and a parking area (including an adapted parking place) will ensure the correct functioning of the site.

The interdisciplinary approach of this project aims to make it easy for visitors to get closer to science in the making. An interpretive plan has been elaborated with this goal in mind.

\section{Interpretive plan}

The main objective of this plan is to «develop a geotourism experience in the palaeontological site and geosite of Montréal-du-Gers». Here are the plan objectives to accomplish it. After studying the resource and the public expected, interpretation objectives, the message we want to transfer and interpretive services have been defined.

Finally, the monitoring and the evaluation of the plan have to be done (Morales, 2001). This way, the service offered will be continuously improved. The analysis will be done for each program. Complementary research and specific recommendations to activate the services should be considered (Morales, 2005).

The bases of this plan are the interpretation principles enounced by Tilden (1957), but also those published by Beck and Cable (1998). These ones were elaborated upon Tilden's original ones, adding other important principles. This is a flexible and open document, which will be adapted to the site and visitor's evolution, taking into account direct observation results, visitors feed back to the site offerings and self-evaluation.

\section{Plan objectives}

To accomplish the objective enounced above, the objectives of the plan are defined.

Management objectives:

- To bring the heritage element closer to the public for its enjoyment.

- To design an interpretation service with a positive influence on visitors.

- To protect the palaeontological site.

Service objectives:

- To define the infrastructures, media and necessities of staff people for an optimal execution of interpretive services.

- To guarantee the access for all publics.

Communication objectives:

- To make visitor discover the importance of the palaeontological site.

- To bring scientific method to the visitors attention and interest.

- To foster a public interest for Science and Natural Heritage in general, Palaeontology in particular.

- To stimulate interest for scientific careers among younger audience.

- To make public aware of looting risks.

\section{The interpretation objectives}

Aiming to give the reasons for the interpretive work, these objectives constitute the reference frame for interpretive actions, strategies and messages.

Management objectives:

- To offer to public a satisfying and quality public service; adequate with 
image projected by the Natural History Museum of Toulouse and the Toulouse City Council.

- To facilitate the use of this space by the public, with a reasonable offer of services, equipments and interpretive programs.

- To assure the protection of the palaeontological site for its conservation.

- To influence the attitudes of public about geological heritage through a delivery of basic concepts.

Service objectives:

- To provide the Interpretation Service with trained and sufficient interpretive staff to execute, monitor and evaluate interpretive programs and design new ones.

- To provide the infrastructures with sufficient media environment.

- To provide access to disable people to site installations and content.

Communication objectives:

- To introduce the concepts of geological heritage, geodiversity and geosite.

- To show the importance of the site as a source of information to reconstruct the past of the region.

- To point out the most outstanding palaeontological aspects of the area.

- To show the apparition and extinction of species as an evolution process.

- To highlight the connection of humans with local environmental resources.

\section{The message}

The thematic approach to heritage interpretation has been used, like a strategy focused in producing results (Ham,
1992). The message expressed is in line with communication interpretation objectives. Contents include interpretive themes, sentences we want public to remember. The objective of this document is not to get deeper in the themes, but to show the basis to be followed to carry out this interpretive plan.

\section{The interpretive services}

In this paragraph of the plan, a prevision of the infrastructures and facilities to implement in the site has been carried out in order to transmit the message to the visitor in an organized and coherent way.

The implantation of different kind of panels taking into account their localisation and functioning is necessary. These panels will include several levels of reading with an interpretive theme as title. A main point will be followed by more detailed information. Various languages, included Braille, will be considered.

Panels recommended and ideas for their implantation:

- Big vertical panels: at the entrance, they will introduce the site and include visits guidelines. This kind of panel may be suitable to show the geological context and conclusions, key ideas or concepts to give a final image or synthesis of the visit.

- Horizontal panels: this kind of panel is suited to explain the findings. Placed around the excavation site, they will join contents and remains in situ. This way, interpretive contents and real objects will be in direct connection. Contents like the geological history or the methodology of the palaeontological studies can be well explained on this kind of support. 
These panels are practical to delimitate the working area and the visitor's area. Obviously, panels must not cover the views on the excavation.

- Small panels can be useful for specific activities.

It is interesting to include simple handson activities in which visitors feel like palaeontologists in order to help them assimilate concepts. These activities will be also useful for visitors with vision disabilities. Finally, the consultation of publications will be possible as long as there is staff available.

A geological cut in situ will show the different strata with two fossiliferous levels.

Services should include the following interpretive programs:

- Teenager's summer placements programs.

- University students program.

- High schools and other teenagers groups program.

- Scholars program.

- Interpretive program for occasional visitors (individual, family or group visits).

- Programs for specific groups needs.

- Self-guided interpretive program through digital media.

\section{Conclusions}

Montréal-du-Gers is a significant element of geodiversity and geological heritage, representative of the geological history of the Midi-Pyrénées region, and rightfully listed in geosites inventories. Teenagers and university students have been doing excavation work on this site for about two decades. Data obtained has created new scientific knowledge.

The Natural History Museum of Toulouse aims to provide access for everyone to this relevant site through a geotourism experience or didactic programs.

Thematic interpretation has been planned. The planning objectives, the interpretation objectives, the main message, and interpretive services have been thought out. After its implementation, the valorisation must be evaluated. Only this way, we can confirm the achievement of the objectives and rethink and actualise the plan in base to its real scope.

Both archaeology and palaeontology finding are not necessarily obvious and easy to grasp to visitors if left by themselves. They should be clarified and made more tangible to them. This must be carefully anticipated and this is what this project intends to do.

\section{Acknowledgements}

The Project Origenes EFA 127/09 is co-funded in a rate of $65 \%$ FEDER under the frame of the Territorial Cooperation Operational Program Spain-France-Andorra (POCTEFA), 2007-2013. We would like to thank all colleagues from the Muséum d'Histoire Naturelle de Toulouse and the Mairie de Toulouse their efforts in the development of this project. 


\section{References}

Antoine, P. O. and Duranthon, F. (1997). «Découverte de Protaceratherium minutum (Mammalia, Rhinocerotidae) dans le gisement orléanien (MN4) de Montréal-du-Gers (Gers)». Annales de Paléontologie, 83: 201-213.

BECK, L. and CABLE, T. (1998). Interpretation for the $21^{\text {st }}$ Century-Fifteen Guiding Principles for interpreting Nature and Culture. Champagne: Sagamore Publishing.

Commission Regionale du PATRIMoine GÉOlogiQue (unpublished). Inventaire du Patrimoine Géologique de Midi-Pyrénées.

Crouzel, F.; Duranthon, F. and Ginsburg, L. (1988). «Découverte d'un riche gisement à petits et grands mammiferes d'âge Orléanien dans le département du Gers (France)». Comptes Rendus de l'Académie des Sciences, 307 (II): 101-104.

De Brujin, H.; DaAms, R.; Daxner-Höck, G.; Fahlbusch, V.; Ginsburg, L.; Mein, P. and MorAlES, J. (1992). "Report of the RCMNS working group on fossil mammals, Reisenburg 1990». Newsletter Stratigraphie, 26 (2/3): 65-118.

De Wever, P.; Le Nechet, Y. and Cornee, A. (2006). Vade-mecum pour l'inventaire de patrimoine géologique national. Paris: Mémoire Hors Série Société Géologique de France, 12.

Duranthon, F. (unpublished). Montréal du Gers: Quand la Gascogne était une jungle. Collection Pour en savoir davantage.

DURANTHON, F. and SAROT, E. (2006). "Valorisation et protection d'un gisement paléontologique grâce aux activités éducatives». In: Première rencontre sur la préservation du patrimoine paléontologique, Marrakech, 27-29 Avril 2006.

Duranthon, F.; Moya Sola, S.; Astibia, H. and KÖHLER, M. (1995). «Ampelomeryx ginsburgi nov. gen., nov. sp. (Artiodactyla, Cervoidea) et la famille des Palaeomerycidae». Comptes Rendus de l'Académie des Sciences, 321 (II a): 101-104.

Duranthon, F.; Antoine, P. O.; Bulot, C. and Capdeville, J. P. (1999). «Le Miocène inférieur et moyen continental du bassin d'Aquitaine». In: Livret-guide de l'excursion des Journées Crouzel, 10 et 11 juillet 1999. Toulouse: Bulletin de la Société d'Histoire Naturelle de Toulouse, $135: 79-91$.

Ham, S. H. (1992). Interpretación ambiental, una guia práctica. Colorado: North American Press.

Morales, J. (2001). Guía práctica para la interpretación del patrimonio: El arte de acercar el legado natural y cultural al público visitante. Sevilla: Dirección General de Bienes Culturales. Junta de Andalucía and TRAGSA.

- (2005). La planificación interpretativa asegura la excelencia en interpretación [WWW] Available from: <http://interpretaciondelpatrimonio.com/docs/pdf/Planificacioninterpretativa.pdf> [Accessed: 14/06/2012].

OrliaC, M. (2006). "Eurolistrodon tenarenzis, sp. nov., from Montréal-du-Gers (France): implications for the systematics of the european Listriodontinae (Suidae, Mammalia)». Journal of Vertebrate Paleontology, 26 (4): 967-980.

Orliac, M.; Antoine, P. O. and Duranthon, F. (2006). "The suoidea (Mammalia, Artiodactyla), exlusive of Listriodontinae, from the early Miocene of Béon 1 (Montréal-du-Gers, SW France, MN4)». Geodiversitas, 28 (4): 685-718.

Tilden, F. (1957). Interpreting our Heritage. Chapel Hill: The Univesity of North Carolina Press.

Welcomme, J.-L. and Crochet, J.-Y. (1996). Inventaire de Patrimoine Paléontologique du Département de Gers. Direction Régionale de l'Environnement Midi-Pyrénées (Toulouse), fiche 65. 
